\title{
THE ROLE OF INNOVATION AND ICT'S IN THE ENERGY MANAGEMENT SECTOR
}

\author{
Youssef Tabsh $^{1}$, Vida Davidavičiené⿱ ${ }^{2}$ \\ ${ }^{1,2}$ Department of Business Technologies and Entrepreneurship, Faculty of Business Management, \\ Vilnius Gediminas Technical University, Saulètekio al. 11, LT-10223 Vilnius, Lithuania \\ E-mails: ${ }^{1}$ youssef.tabsh@lau.edu; ${ }^{2}$ vida.davidaviciene@vgtu.lt (corresponding author)
}

\begin{abstract}
Sustainability and innovation are strongly connected in terms of productivity and finding innovative solutions for the short and the long terms. The purpose of this article is to analyze ICT models for innovation and sustainable development processes in the energy management sector and to identify possible solutions (Lebanese case). Using the comparative analysis method, the article will illustrate the difference between using ICT models in innovation and sustainability in energy management and the previous models used for energy production and management focusing on the results after implementation.
\end{abstract}

Keywords: sustainability, energy, management, ICT, innovation.

JEL Classification: M11, O30, O31, O32.

\section{Introduction}

The world is living now in an era where most of our daily life devices are connected directly or indirectly to the internet. The information and communication technology (ICT) is the base for any technological improvement for any products, services and even processes that are created by the public and the private sectors. Information and communication technologies and their based innovations will provide very potential cost-effective solutions for the communities and the countries to deliver the essential and very urgent changes needed in the energy management sector (Jáñez Morán, Profaizer, Herrando Zapater, Andérez Valdavida, Zabalza Bribián, 2016). ICT for energy management systems and resource incorporation should be taken into consideration in order to increase the productivity and to sustain the resources used on daily bases. ICT surely will have an essential yet positive effect on energy production, direct and in indirect ways (OlloLópez \& Aramendía-Muneta, 2012; Røpke \& Christensen, 2012; Bekaroo, Bokhoree, \& Pattinson, 2016).

There are main challenges that are facing the world in the energy sector, the main concerns are:

- Reduce the energy consumption

- Find low cost and low carbon emission energy supplies
- Replace the current fuel producing power plants to alternative fuel and sustainable energy resources

- Implement new technologies and share the knowledge about new inventions that might help the energy sector

- Governments should be really strict in taking smart and green decisions and finally the world should be open to ICT innovation in this sector.

Since most of the developing countries including Lebanon are facing problems with the energy sector, the scientific problem of this article is finding the best possible solution using information and communication technologies integration in the energy sector.

Energy sector mainly can benefit from the integration between the innovation and the information and communication technologies in order to have sustainable solutions on the long run. Innovation activities and technological advance in all spheres of social and economic life, as well as creation of knowledge based society and knowledge economy in general could be defined as an especially important priority of the development processes and changes in the society, its life and culture under contemporary conditions of globalization (Raudeliūnienè \& Davidavičius, 2017; Raudeliūnienè, Stadnik, \& Kindarytè, 2016; Melnikas, 2016). 
Innovation is the key element for moving the energy management concept from the current position to a futuristic innovative sustainable level (Antonioli \& Mazzanti, 2017; França, Broman, Robèrt, Basile, \& Trygg, 2017; Naber, Raven, Kouw, \& Dassen, 2017). The energy scare resources nowadays are on their way to cessation in the next hundred years because of the increase of energy needs and climate change, therefore, the combination of information and communication technology with innovation must reach to a level where they must help the energy management systems to sustain the current scare resources and improve the sector to satisfy the increase of energy needs and to cope with the climate change (Sokona, Mulugetta, \& Gujba, 2012; Ishida, 2014; Staub, Kaynak, \& Gok, 2016; Naber et al., 2017). The innovation solutions must be created and designed to solve issues of economics, feasibility, and safety in the energy management sector developmental approach.

The developmental approach must include all major technology breakthroughs in power sources, grids, energy storage, and ICT (Z. Liu \& Z. Liu, 2015). The results of the technological developments should focus on the productivity of the power sources, manage the distribution process and finally keep the system error and problem free. Social responsibility in addition to the political obligations appear to be the primary motivation for the futuristic developmental approach (Ngar-yin Mah, Wu, \& Ronald Hills, 2017). Then the governments should work to put all of the political problems aside and work together in order to achieve a policy that will lead to the implementation of the development of the energy sector. The social actors should also collaborate and put their efforts with the governments not only for supporting the process rather than to find applicable solutions and provide studies to choose the best option that might the governments choose for implementation.

The solutions for the energy supply deficiencies vary, every solution can depend on the country geographical location on the map and its' nature. The key areas of innovation in the sustainable energy production include wind, solar, ocean power, distributed generation, and other renewable energy technologies (Z. Liu \& Z. Liu, 2015). The investments in the sustainable energy solutions can have a major impact on the development of the countries that are lacking the energy power supply, or still using the oil to produce energy (Buracas, 2016; Mosannenzadeh et al., 2017; Silvast, 2017).
The purpose of this article is to analyze ICT models for innovation and sustainable development processes in the energy management sector and to identify possible solutions (Lebanese case).

For reaching such methods as literature analysis, synthesis, survey and descriptive data analysis was employed.

\section{ICT use: challenges and opportunities}

Scientists are considering the information and communication technologies as the futuristic solution for many problems that the governments are facing locally and globally. They also defined ICT as a technology that is used for general purposes, which is convincing, credible and the potential of spreading quickly is very high, it expedites and persuades firms to adopt more effective and efficient structural forms (Bekaroo et al., 2016; Buracas, 2016; Liao, Wang, Li, \& Weyman-Jones, 2016). The purpose of using the ICT's in various fields and sectors it's because the ability of it to be functional and helpful in developing solutions for many operational complications. New technologies can help economies, industries and firms grow and succeed, and the large number of government initiatives to foster the spread of ICT is testament to the expectation that ICT has a broad societal impact that may even go beyond the economic effects (Cambini, Ward, \& Kretschmer, 2013). ICT role as a technological tool is to open job opportunities and generate income, is to expand access to help meet their social and economic development objectives and also to extend ability to use technologies in order to reach the development objective of a country (Savulescu, 2015).

When talking about new technologies, it directly reflects on innovation and how the invention of new technologies can push towards finding new sustainable and affordable solutions for energy management in the developing countries. When talking about energy management, the most immediate energy priority for developing countries is to expand access to help meet their social and economic development objectives (Sokona et al., 2012). From here we see that the development of the energy sector can help the developing countries to have more stable economic situations which will lead to the development of society itself. Not to forget that the innovation lead by the information and communication technologies will play a major role in providing cost effective solutions for the countries and the communities together. 
Modern countries and cities are developed and managed basically taking into consideration the significance for sustainable development, several inventiveness have emphasized how ICT can be used to achieve cities' powering targets by using effectively and efficiently the scarce sources of energy (Tabsh \& Davidavičiene, 2016). The sustainability in developing countries opens a statement about the possibility to improve the lives of the people living in these countries. Not to forget the financial, educational and psychological problems that are main factors facing these implementations. Information and communication technologies are the way of which we should use to successfully complete any sustainable development project, the main reason for that is communication is determining the world widely and rapidly. Once a specific information and communication technology (ICT) innovation has been decided on, it is usually in everyone' $s$ interest to make it work as efficient as possible, and a crucial part of the knowledge concerning how to do so is usually dispersed among people working with the ICT innovation in their daily routine (Hansen \& Nørup, 2017). Innovation in the energy management systems should be linked to a strategy and business planning process, as innovation separates to business strategy, it might be a very high risk of converting the key resources and destructing the focus on goals and targets of an organization. Innovation if not managed in the right direction, it could be a great aspect of losing resources and time, thus, putting the right efforts for innovation in any organization can be a turning point for success and achievements (Sokona et al., 2012; Lee \& Trimi, 2016; Antonioli \& Mazzanti, 2017; Tayal, 2017).

As long as the innovation is put in the right direction to help the developing countries, the more the innovation the more it will be helpful and useful to achieve countries targets and goals. Innovation if it is not managed in the right direction, it will have a huge impact on loosing resources and time. Putting the right efforts for innovation in any developing country can be a turning point for success and achievements (Edomah, Foulds, \& Jones, 2017). That's why linking ICT's to innovation management will lead to results in managing the current energy resources and in innovating new strategies in producing renewable energy and managing it. Innovation is the art of creating and inventing new ideas and effectively putting them in people's hands to solve difficulties and create chances (Z. Liu \& Z. Liu, 2015).

\section{Sustainability and innovation in energy management}

Sustainability and innovation are strongly connected in terms of productivity and finding innovative solutions for the short and the long run (Rutkauskas, Stasytytè, \& Michnevič, 2014; Lee \& Trimi, 2016; Ngar-yin Mah et al., 2017). Many countries are persuaded that the more green and environment friendly they are, the less the effort is needed to save the earth from pollution. Countries believe that the additional costs put in the diversion from the traditional energy production and energy management to an innovative power supply system will definitely pay off on the long term (Ishida, 2014; De Vries, Boon, \& Peine, 2016; Tabsh \& Davidavičienè, 2016; Silvast, 2017). The pursuit for sustainability is starting already to transform the economic structure, which will lead the countries to change the way they think about processes, technologies, and services provided to their citizens (Silvast, 2017). These changes will force the countries to go through a path of change that will divert the production process of the energy supplies that they are producing these days. Going green is really cost effective and cost efficient, as the developing countries are going into green energy production, this will play a major role in reducing the cost of the produced energy in the future because the cost that will be invested nowadays will be an asset (Zhang \& Liang, 2012; Liao et al., 2016; Antonioli \& Mazzanti, 2017). For example, when a country replaces the electrical supply from the traditional gas source to the solar panels, this will cost the country a bit at the beginning but on the long run, the country will reduce the electricity bill on their citizens, thus the cost of the electrical supply paid on monthly basis will be reduced which will lead to economical enhancement in the societies. Today, countries have no choice but to heed mandates and satisfy environmental standards set by the European Union (EU) and the World Energy Council (WEC). These standards are set by the World Energy Council and they defined the energy sustainability that rely on three fundamental pillars: energy security, energy equity, and environmental sustainability, putting balance for these three goals creates a 'Trilemma'.

The "Trilemma" is the basis for wealth and attractiveness of the countries, the plan introduced in 2010 contains goals of producing more of power generation from renewable and green sources, also one of the goals is to reduce the oil energy production and usage in addition to the 
Carbon Dioxide emissions (World Energy Council \& Wyman, 2016).

In this phase, the responsibility is on the governments and the policy regulators to put an action plan for the transition from the traditional energy production to more advanced and clean energy production. For sure that the citizens need this enhancement in the energy management sector for economic and social reasons, the more the people are involved in the making of the new policies, the more they will be adaptable in accepting the new change.

For sure, the need for sustainability is starting to convert the landscape competitiveness, which will put pressure on governments to change the way they think about products, services, technologies, business models and processes (Nidumolu, Prahalad, \& Rangaswami, 2009).

Developing explicit criteria and putting a tool to measure the performance against the set objectives of involving the technology with innovation to develop a new energy management system will surely become an essential motive of behavior transformation within the governments in the developing countries. This also will ensure that sustainability will be on the full scheme of being used and getting the correct output for enhancing the future of the developing countries.

\section{ICT and innovation in energy management}

The past years have witnessed spectacular improvements in Information and Communication Technology (ICT) diffusion and innovation. Putting devotion and innovation in ICT has been significant worldwide, with important effects on telecommunication infrastructure. Information and communications technology has clearly transformed our daily life, the role of ICT as a major factor in resolving a wide range of universal challenges is often unnoticed. ICT in collaboration with innovation have the ability to transform the lives of people around the world, especially in developing and developed countries as well. ICT alone doesn't have the ability to solve all of the energy management problems in the world, but it can and should be a major element of solutions. ICT and innovation can be measured as a process that compiled two major components or elements, the introduction and implementation stages. The introductory phase requires the generation of innovative and useful ideas that can be accepted in coming up with useful solutions for the energy management sector in the developing countries and to make it useful at the implementation stage.
Innovation seems to be a major factor for the effective implementation and use of new technologies. Regional innovation cultures emphasize the importance of certain regional characteristics, such as habits and routines, institutional frameworks, and the level of expertise and resource networks that may favor the transformative uses of ICT, and therefore its possible impacts.

The innovation is highly connected to the information and communication technologies, in our century the more we focus on creating innovative solutions to help the energy management industry that we focus on, the more we succeed to push this industry to the next level of effectiveness and efficiency. The ICTs can work directly with the innovative solutions to monitor, control and adjust processes during the energy management enhancement project execution. The more high technology we have, the more we will be able to control and the more we will be able to accomplish our targets. To be more innovative by using ICTs, smart clouds or intelligent clouds can be used to save, transform and share data with other users. Intelligent clouds is going to create new value connections in the energy management industry. Some of the indications can include data mining, data sharing, and data compiling. By using the intelligent clouds, new chances will open for all the people who are involved in this connection chain from the manufacturer which can be the government or the private sector to the customer. On the other hand, technology is offering new instruments and tools to engage customers through online platforms, social media, and customer relationship management. Because of that, customers work in a better way as brand representatives and co-designers of value. In this sense, technology grants service firms new means to fundamentally change the context in which they deliver services, such that they can establish and maintain more personalized customer relationships. Many firms acknowledge the importance of engaging and nurturing the creativity of their employees. Such firms offer initiatives to ensure the people within the organization have appropriate environments and support, to nurture their creativity and innovation (Rutkauskas et al., 2014; França et al., 2017).

Another aspect of innovation is using the smart devices connected to the information and communication technologies. Smart devices is changing our lives in many ways, these ways range from simple tasks to do such as ordering some food using mobile applications, to funda- 
mentally new business opportunities that is involving services to be invented and markets to be discovered. Combined with innovative and intelligent data management processes, smart devices can improve the productivity and profitability in more effective and efficient procedures in any businesses.. In order to enable the distribution of smart devices, these devices should be cost effective and the cost of managing and monitoring these devices must be low and affordable. The role of the smart devices in the energy management systems is very important and crucial, using the smart devices will give feedback about the energy consumption, any technical problem that is currently happening and finally it will be used to determine any futuristic problem with any energy production device connected to the system.

An incorporated energy sector market is wanted to generate more competition between the companies generating energy, which will lead to higher market proficiency through improved use of energy generating facilities throughout the world and to provide reasonable prices for consumers (Silvast, 2017). The theoretic problem of creating a sustainable and innovative energy management system is that most of the developing countries are controlled by corrupted governments (Tabsh \& Davidavičienè, 2016). ICTs hardware and software cannot work without electricity, on the other hand, energy management systems in the developing countries must depend completely on ICTs to have the appropriate improvements in the sector. ICT tools allow exchange of information: websites, social networks, and project management tools such as wiki, podcasting and information retrieval tools (Davidavičienė \& Raudeliūnienè, 2010).

\section{Energy sector problem - Lebanon case}

Lebanon, since the war against Israel in the summer of 2006, is facing a catastrophic situation in the electricity provided by the Ministry of Electricity, because during the war, the major electrical power generator plants were destroyed. Lebanese government nor the municipalities are unable to fulfill their duties in implementing the renewable energy systems due to legal constraints and financial dependency. The two major financial resources for municipalities the Independent Municipal Fund (IMF) and the local taxation- are not sufficient to promote community development and sustainability initiatives (Khoury, 2012). Moreover, the municipalities lack the essential technical guidance and capacity to apply to external loans and grants provided by bilateral and multilateral agencies, which keep the necessity level very high in providing the citizens with alternative solutions other than the electricity provided by the government. Forty years ago, Lebanon used to produce enough power to be able to export a part of it to Syria, the largest neighbor. Currently, Lebanon is barely able to cater for its national energy demands, there is hardly enough electricity to keep street lamps on at night. The current situation is horrible that even refugees fleeing the conflict in Syria are complaining. The governmental paralysis and the corruption affecting the developmental strategies in Lebanon has started since the civil war and it is continuing till our present times.

In a country where the gross national income per capita is $\$ 9,800$, according to the latest World Bank estimates, the Lebanese families spent on average of $\$ 1,300$ on electricity, around $\$ 900$ on generators owned by locals in the neighborhoods during the year of 2016.

A survey was conducted by the authors in Beirut, Lebanon during the fall of 2017 about the renewable energy, the aim of the research was to know more the Lebanese citizen's awareness about renewable energy available. Sample size of 386 calculated taking 61.3 percent (age 15-65) of inhabitants from all 6 million populations with confidence level 95 percent, confidence interval 5 . In total 200 completed questionnaires were collected in Beirut. The results show two major factors in this survey. The first factor was the Lebanese participants were unaware of the renewable energy supplies available in the market and the second factor was that the participants have hesitancy in having these new devices for many reasons. The responsibility here is on the government who didn't support the suppliers to have these power supply systems by reducing the taxes on such devices, and in addition the Ministry of Energy didn't do the right approach in conducting awareness sessions for the citizens giving them the benefits of having solar energy systems at their places.

$43 \%$ are very aware of the solar energy technologies, $52 \%$, are little aware of the solar energy technologies. From the above results, were noticed that the majority of the participants $52 \%$ are little aware of the solar energy technologies, this because the solar energy technologies entered the Lebanese market very recent, people in general are curious about anything new but they are afraid 
of trying this technology, the government is not helping the suppliers in doing enough marketing campaigns to attract customers. $43 \%$ are very aware because we are living in a technological era where everything is available online, so these people tend to read and search about it to have more knowledge.

The Lebanese citizens in general are unaware of the renewable energy technologies because of the unclear functions of these systems, none of the actors are connecting the features to the benefits of these devices which made them more vicious to the end users (Ibrahim, Fardoun, Younes, \& Louahlia-Gualous, 2013; Khodr \& Uherova Hasbani, 2013; Al Zohbi, Hendrick, \& Bouillard, 2015). The second question was about the factors that preventing the customers to have the solar energy power systems at their places. The results were very logical here, affordability came first, then the lack of awareness. This support the author's opinion that the awareness sessions and the price of these devices should be available to every Lebanese citizen. The below figure shows in details the results collected from this survey about this question.

The majority of the participants $43 \%$ can't have solar energy technology at their homes because they can't afford it, the prices of this technology is very high in Lebanon and the government is not helping that much in supporting the citizens to have solar energy at their homes. $20 \%$ of the participants lack awareness, the government and the suppliers of the solar energy technology are not doing the right marketing campaigns to encourage the people on buying this technology. The cost of the solar panels ranges from $\$ 10,000$ to $\$ 35,000$ for most households, the loans are making this an attractive option. Difficulties are still there. Most of the people live in the cities where they don't have space for the solar energy panels on the roofs, add to it there is still not much awareness about renewable energy in the country. $18 \%$ finds it in convenient to install solar energy while $10 \%$ of the participants have solar energy technology installed at their homes, these people for sure have high income and they are able to use this technology at their homes, the payback of installing the solar energy technology is calculated in around 7 years after installing the solar panels, after 7 years, whatever the duration is, it will be as a winning stage for the owner as the solar energy system will be for free.

The final question had the sharp answer for the government and for the private sector, the question was if the objections of having the solar power systems were cleared would you buy these power systems? It is that clear that people are interested in the solar energy technology, $96 \%$ gave the acceptance for the solar energy technology if it was cheaper, more convenient, the suppliers and the government make intensive awareness campaigns about it and finally try to build the trust between the participants and the suppliers about the solar energy technology and how useful to install it at their homes.

From the above results we see that the Lebanese people are willing to have a new innovative technology, that's because the majority of the Lebanese society is composed of youth and educated people who are willing to invest money in an energy management system that will save their environment and their money on the long term. In order to evaluate the full consequence of implemented ICT solutions in the energy management systems, it is significant to take into consideration all the direct and the indirect transformations caused by this implementation, including the effect from the ICT solutions through the entire lifecycle. This can lead to the result of the importance of merging the ICT's to the energy management system implementation with policy and planning procedures, to make sure that the efficiency and effectiveness gains actually lead to a reduced use of energy have also been proved.

There are many used prototypes to solve the energy management sector problems in the world, due to the bad economy factors, corruption and regional position, the Indian example can be implemented in Lebanon with some minor adjustments. In India the energy sector was facing a lot of problems, due to several factors that played a negative role in the innovation and in the development of the sector. Thus, Lebanon is facing a lot of these problems yet there is a good hope in doing developmental strategies to the energy management sector in Lebanon by using the Indian prototype. Recent studies showed that India is in the $13^{\text {th }}$ position in using the renewable energy systems (Monforti et al., 2014; Hazarika, Gogoi, Jose, Das, \& Basu, 2017; Zhang \& Xuan, 2017).

\section{Conclusions}

When innovation is linked to the communication and information technology, successful results will certainly appear. The ICT's generally depend on innovation, and with the era of wireless communication and information sharing, the innovation management will play a major role in keeping the ICT's on the right and correct track when it 
comes to monitor and control the energy management systems. ICT's can't solve all the worlds' problems, but at least it will help in providing the needed platform for innovation to take place and be part of the change. When connecting the innovation to the information and communication technologies, a lot of positive results will be linked to the success of the energy management sector, the positive aspects will be counted, such as, creation of innovative solutions for solving the electricity problems for the developing countries, connecting similar projects together to serve the need of the communities for electricity and finally empowering the citizens and the municipalities in adapting and creating new energy management projects and try to implement them on the national level with the help of the government and the help of the ministry of water and power supply.

Nowadays, less than 10 percent of all of the energy used worldwide comes from renewable energy resources, the major question here is why we are not using the renewable energy if is it safe to the environment and it is automatically renewed? The answer is very simple, it is because these energy solutions are expensive and many people don't trust them. Governments should have the ability to encourage the citizens to use these solution, provide support and educate the citizens about the positive aspects of using these solutions. Also the governments should support the suppliers of these systems and make these systems tax free so it can be used by a wide range of people.

ICT's with the support of innovation can be in a great partnership to find sustainable and suitable solutions for the energy management sector in the developing countries. Politicians are the key factor for not implementing these systems and solutions, these politicians must think about the national value for adapting new solutions in order to help their country, otherwise, corruption will be on the other side fighting the new systems and technologies not to enter the market in order not to finish the corruption's era.

\section{References}

Al Zohbi, G., Hendrick, P., \& Bouillard, P. (2015). Wind characteristics and wind energy potential analysis in five sites in Lebanon. International Journal of Hydrogen Energy, 40(44), 15311-15319. https://doi.org/10.1016/j.ijhydene.2015.04.115

Antonioli, D., \& Mazzanti, M. (2017). Towards a green economy through innovations: the role of trade union involvement. Ecological Economics, 131, 286-299. https://doi.org/10.1016/j.ecolecon.2016.09.003

Bekaroo, G., Bokhoree, C., \& Pattinson, C. (2016). Impacts of ICT on the natural ecosystem: a grassroot analysis for promoting socio-environmental sustainability. Renewable and Sustainable Energy Reviews, 57, 15801595. https://doi.org/10.1016/j.rser.2015.12.147

Buracas, A. (2016). ICT impact on competencies and innovations: regional applicability of global indicators. TEM Journal, 5(4), 550-559.

Cambini, C., Ward, M. R., \& Kretschmer, T. (2013). ICT and innovation: editorial. Information Economics and Policy, 25(3), 107-108.

https://doi.org/10.1016/j.infoecopol.2013.07.004

Davidavičienè, V., \& Raudeliūnienè, J. (2010). ICT in tacit knowledge preservation. The 6th International Scientific Conference "Business and Management 2010", Selected Papers, (2006), 822-828. https://doi.org/10.3846/bm.2010.109

De Vries, G. W., Boon, W. P. C., \& Peine, A. (2016). Userled innovation in civic energy communities. Environmental Innovation and Societal Transitions, 19, 51-65. https://doi.org/10.1016/j.eist.2015.09.001

Edomah, N., Foulds, C., \& Jones, A. (2017). Influences on energy supply infrastructure: a comparison of different theoretical perspectives. Renewable and Sustainable Energy Reviews, 79(May), 765-778. https://doi.org/10.1016/j.rser.2017.05.072

França, C. L., Broman, G., Robèrt, K.-H., Basile, G., \& Trygg, L. (2017). An approach to business model innovation and design for strategic sustainable development. Journal of Cleaner Production, 140, 155-166. https://doi.org/10.1016/j.jclepro.2016.06.124

Hansen, M. B., \& Nørup, I. (2017). Leading the implementation of ICT innovations. Public Administration Review, 77, 851-860. https://doi.org/10.1111/puar.12807

Hazarika, D., Gogoi, N., Jose, S., Das, R., \& Basu, G. (2017). Exploration of future prospects of Indian pineapple leaf, an agro waste for textile application. Journal of Cleaner Production, 141, 580-586. https://doi.org/10.1016/j.jclepro.2016.09.092

Ibrahim, O., Fardoun, F., Younes, R., \& Louahlia-Gualous, H. (2013). Energy status in Lebanon and electricity generation reform plan based on cost and pollution optimization. Renewable and Sustainable Energy Reviews, 20, 255-278.

https://doi.org/10.1016/j.rser.2012.11.014

Ishida, H. (2014). The effect of ICT development on economic growth and energy consumption in Japan. Telematics and Informatics, 32(1), 79-88. https://doi.org/10.1016/j.tele.2014.04.003

Jáñez Morán, A., Profaizer, P., Herrando Zapater, M., Andérez Valdavida, M., \& Zabalza Bribián, I. (2016). Information and Communications Technologies (ICTs) for energy efficiency in buildings: review and analysis of results from EU pilot projects. Energy and Buildings, $127,128-137$. https://doi.org/10.1016/j.enbuild.2016.05.064

Khodr, H., \& Uherova Hasbani, K. (2013). The dynamics of energy policy in Lebanon when research, politics, and policy fail to intersect. Energy Policy, 60, 629-642. https://doi.org/10.1016/j.enpol.2013.05.080

Khoury, R. (2012). Lebanon. Recommended National Sustainable Urban and Energy Savings Actions.

https://doi.org/10.1093/oxfordhb/9780195366556.013.0017

Lee, S. M., \& Trimi, S. (2016). Innovation for creating a smart future. Journal of Innovation \& Knowledge, 110. https://doi.org/10.1016/j.jik.2016.11.001

Liao, H., Wang, B., Li, B., \& Weyman-Jones, T. (2016). ICT as a general-purpose technology: the productivity of 
ICT in the United States revisited. Information Economics and Policy, 36, 10-25.

https://doi.org/10.1016/j.infoecopol.2016.05.001

Liu, Z., \& Liu, Z. (2015). Chapter 6 - Innovation in Global Energy Interconnection Technologies. Global Energy Interconnection, 2015, 239-272. https://doi.org/10.1016/B978-0-12-804405-6.00006-3

Melnikas, B. (2016). Innovation management studies: technological advance and challenges of globalization. 9th International Scientific Conference "Business and Management. Vilnius Gediminas Technical University, Faculty Business Management, Vilnius, Lithuania. https://doi.org/10.3846/bm.2016.33

Monforti, F., Huld, T., Bódis, K., Vitali, L., Isidoro, M. D., \& Lacal-arántegui, R. (2014). Assessing complementarity of wind and solar resources for energy production in Italy. A Monte Carlo approach. Renewable Energy, 63, 576-586.

https://doi.org/10.1016/j.renene.2013.10.028

Mosannenzadeh, F., Bisello, A., Vaccaro, R., D’Alonzo, V., Hunter, G. W., \& Vettorato, D. (2017). Smart energy city development: a story told by urban planners. Cities, 64, 54-65.

https://doi.org/10.1016/j.cities.2017.02.001

Naber, R., Raven, R., Kouw, M., \& Dassen, T. (2017). Scaling up sustainable energy innovations. Energy Policy, 110(June), 342-354. https://doi.org/10.1016/j.enpol.2017.07.056

Ngar-yin Mah, D., Wu, Y. Y., \& Ronald Hills, P. (2017). Explaining the role of incumbent utilities in sustainable energy transitions: a case study of the smart grid development in China. Energy Policy, 109(June), 794-806. https://doi.org/10.1016/j.enpol.2017.06.059

Nidumolu, R., Prahalad, C. K., \& Rangaswami, M. R. (2009). Why sustainability is now the key driver of innovation. Harvard Business Review, 87(9), 57-64. https://doi.org/10.1109/EMR.2013.6601104

Ollo-López, A., \& Aramendía-Muneta, M. E. (2012). ICT impact on competitiveness, innovation and environment. Telematics and Informatics, 29(2), 204-210. https://doi.org/10.1016/j.tele.2011.08.002

Raudeliūnienè, J., \& Davidavičius, S. (2017). A conceptual model of assessment of knowledge transfer to consumer. Business, Management and Education, 15(2), 174-195. https://doi.org/10.3846/bme.2017.387

Raudeliūnienè, J., Stadnik, B., \& Kindarytè, R. (2016). Knowledge appliance process: theoretical and practical evaluation aspects. Entrepreneurship and sustainability issues, 3(4), 368-379.

https://doi.org/10.9770/jesi.2016.3.4(5)
Røpke, I., \& Christensen, T. H. (2012). Energy impacts of ICT - insights from an everyday life perspective. Telematics and Informatics, 29(4), 348-361. https://doi.org/10.1016/j.tele.2012.02.001

Rutkauskas, A. V., Stasytyte, V., \& Michnevič, E. (2014). Universally sustainable development strategy for a small country: a systemic decision. Engineering Economics, 25(5), 530-537. https://doi.org/10.5755/j01.ee.25.5.3797

Savulescu, C. (2015). Dynamics of ICT Development in the EU. Procedia Economics and Finance, 23(October 2014), 513-520. https://doi.org/10.1016/S2212-5671(15)00552-3

Silvast, A. (2017). Energy, economics, and performativity: reviewing theoretical advances in social studies of markets and energy. Energy Research and Social Science, 34(October 2016), 4-12. https://doi.org/10.1016/j.erss.2017.05.005

Sokona, Y., Mulugetta, Y., \& Gujba, H. (2012). Widening energy access in Africa: towards energy transition. Energy Policy, 47(Suppl. 1), 3-10. https://doi.org/10.1016/j.enpol.2012.03.040

Staub, S., Kaynak, R., \& Gok, T. (2016). What affects sustainability and innovation - hard or soft corporate identity?. Technological Forecasting and Social Change, 102(5), $72-79$. https://doi.org/10.1016/j.techfore.2015.06.033

Tabsh, Y., \& Davidavičienè, V. (2016). Information and Communication Technologies in Energy Management. Journal of System and Management Sciences, 6(4), 6781.

Tayal, D. (2017). Leveraging innovation for electricity utilities. Electricity Journal, 30(3), 23-29. https://doi.org/10.1016/j.tej.2017.02.008

World Energy Council \& Wyman, O. (2016). World Energy Trilemma Index 2016, 147. Retrieved from https://www.worldenergy.org/wp-content/uploads/2016/10/Full-report_Energy-Trilemma-Index2016.pdf

Zhang, J., \& Liang, X. J. (2012). Promoting green ICT in China: a framework based on innovation system approaches. Telecommunications Policy, 36(10-11), 9971013. https://doi.org/10.1016/j.telpol.2012.09.001

Zhang, J., \& Xuan, Y. (2017). Performance improvement of a photovoltaic - thermoelectric hybrid system subjecting to fluctuant solar radiation. Renewable Energy, 113, 1551-1558. https://doi.org/10.1016/j.renene.2017.07.003 